\title{
PENGGUNAAN STANDARD ISO 9126 \\ UNTUK MENGEVALUASI KEEFEKTIFAN PERANGKAT LUNAK
}

\author{
Agus Sukoco ${ }^{1)}$ \\ ${ }^{1}$ Program Studi Teknik Informatika \\ Fakultas llmu Komputer \\ Universitas Bandar Lampung
}

Jln. Z.A. Pagar Alam No.26 Labuhan Ratu Bandar Lampung 35142

Telp. (0721) 701463, (0721) 701979 Fax. (0721) 701467 Web. www.ubl.ac.id

E-mail: kcool6@yahoo.com ${ }^{1)}$

Handphone: $081514356424^{11}$

\begin{abstract}
Abstrak
Mengevaluasi perangkat lunak yang telah diumpelementasikan dalam sebuah perusahaan merupakan elemen penting dari sebuah penjaminan proses pengembangan rekayasa perangkat huak dewasa ini. Deganan demikian perusahaan yang telah berintegrasi dengan perangkat lunak di dalam proses binismya, harus mengevaluasi perangkat lunak dingan memantau serta mengukur karakteristik perangkat hinak yang dihasilkan untuk membuktikan bahwa persyaralan perangkat lunak yang dinginkan teiah dipenuhi pengunaamya. Maka, berkaitan dengan hal tersebut diperlukan pengtukuran dan pemantauan berupa evaluasi perangkat lunak yang efektif yang dihasilkan sesuai dengan standard yang telah ada.

Salah satu sfandard yang bisa digunakan umuk mengevahuasi kualiass sofhware yautu Standard 150 9126. Standard ini merupakan saiah satu frame work umum mengenai karakterisuk dari kaalitas perangkat lunak, yang dipercaya mempumyai kekuatan yang lebih adaptable yang dapat digunakan wituk seluruh sistem, terutama untuk menetapkan kerangka umum dalam mengevaluasi sebuah software. Sehingga pihak manajemen akan lebih akurat dalam memperoleh informasi untuk menentukan keputusan strategis.
\end{abstract}

Kata Kunci : ISO 9126,Aplikasi Wizard, Pengukuran Sofmoare.

\section{PENDAHULUAN}

Pemanfastan teknologi informasi sangat berkaitan erat dalam pengembangan bisnis dewasa ini, faktor penting dalam perkembangan tersebut juga sangat dipengaruhi oleh kualitas perangkat lunak (Soffware), terutama sebagai interaksi pengguna dengan perangkat keras (hardware). Sehingga dalam bisnis prosesnya, ada beberapa perusahaan yang mulai bergantung dengan perangkat lunak. Saat ini perangkat lunak sudah menjadi kekuatan yang. menentukan, dan menjadi mesin yang mengendalikan pengambilan keputusan di dalam dunia bisnis (Pressman, $2003=$ p2-3). Pengelolaan perangkat lunak sebagai pengambilan keputusan yang strategis. tentunya hanus ditunjang oleh sistem dan perangkat lunak yang berkualitas, Maka diharapkan management dapat memperoleh informasi sebagai sumberdaya yang strategis dan informasi yang betkualitas.

Agar perangkat lunak dapat terjamin dengan baik, maka diperlukan pengendalian dan pengelolaan yang mengacu pada kualitas perangkat lunak. Jaminan kualitas perangkat lunak merupakan aktivitas mendasar bagi banyak bisnis yang menghasilkan produk yang akan digunakan olch user baik intemal perusahaan maupun eksternal. Untuk memperoleh kualitas perangkat lunak yang diharapkan, mengevaluasi kualias produk suatu perangkat lunak menupakan elemen kritis dari jaminan perangkat lunak sehingga dapat merepresentasikan kajian pokok dari spesifikasi, desain dan pengkodean (Pressman, 2003 : p216-217). 
Pengendalian untuk memperoleh kualitas prangkat lunak yang sesuai diharapkan dengan visi, misi dan tujuan organisasi merupakan elemen kritis bagi perusahaan. Sehingga pengujian perangkat lunak yang mengacu pada standard tertentu patut dilakukan. Terutama bagi perusahaan yang sudah menerapkan sistem manajemen mutu yang mengacu pada standar ISO 9001:2008, di dalam standard ISO 9001:2008 klausul 6.3 (b) tertulis bahwa suafu perusahaan harus memperhatikan dalam penyediaan dan pemeliharaan infrastruktur sofhvare. Pemeliharaan software yang dikaitkan dengan klausul 8.2.4. yakni organisasi harus memantau dan mengukur karakteristik produk yang dihasilkan untuk membuktikan bahwa persyaratan produk telah dipenuhi. Maka, berkaitan dengan hal tersebut diperlukan pengukuran dan pemantauan berupa evaluasi software yang efektif yang dihasilkan sesuai dengan standard yang telah ada.

Salah satu standard yang bisa digunakan untuk mengevaluasi kualitas sofnware yaitu Standard ISO 9126. Standard ini merupakan salah satu frame work umum mengenai karakteristik dari kualitas perangkat lunak, yang dipercaya mempunyai kekuatan yang lebih adaptable yang dapat digunakan untuk seluruh sistem, terutama untuk menetapkan kerangka umum daham mengevaluasi sebuah soffware (Bee Bee Chua, 2004 : p 185), sehingga dapat mengevaluasi keefektifan dan kualitas perangkat lunak, dan mendeteksi kesalahan potensial, sehingga visibilitas perangkat lunak suatu elemen sistem dan biaya yang muncul akibat kegagalan perangkat lunak, dapat ditekan.

PT SMI yang telah mengimplementasikan ISO 9001 : 2008, berdasarkan acuan standardnya terutama untuk peningkstan yang berkelanjutan, khususnya di divisi IT dituntut memperoleh andil dalam peningkatan tersebut. Untuk memenuhi peningkatan yang berkelanjutan tersebut, divisi IT yang meaghasilkan perangkat lunak harus memantau dan mengukur produk yang telah dihasilkan. Divisi IT harus memantau dan megukur karakteristik produk untuk membuktikan bahwa perangkat lunak yang dihasilkan telah memenuhi persyaratan, sehingga perencanaan produk yang sesuai yang direncanakan akan tercapai. Dengan demikian persyaratan 1SO 9001:2008 dan sasaran mutu dari divisi IT dapat terpenuhi dengan baik.

Dari hasil internal audit yang dilakukan secara teratur dan terencana, terdapat temuan yang sampai saat ini belum diselesaikan, sehingga karena temuan tersebut telah ditetapkan sebagai temuan yang harus $\mathrm{di}$ agendakan dalam rapat tinjauan manajemen, temuan tersebut yaitu pengukuran dan pemantauan dalam hal ini mengevaluasi keefektifan software yang telah diimplementasikan oleh divisi IT. Sehingga keefektifan dan ktalitas dari perangkat lunak pada saat ini belum dapat diketahui kehandalannya. Hal ini menyulitkan untuk mengevaluasi perangkat lunak secara produk secara periodik dengan sistem yang efektuf dan efisien.

Oleh karena itu, diperlukan alat bantu untuk mempermudah melakukan pengujian sojtware tersebut, sehingga diperlukan pengembangan sebuah aplikasi yang mampu mendukung. aktivitas evaluasi dari pengukuran kualitas perangkat lusak berdasarkan ISO 9126.Sehingga pihak manajemen akan lebih akurat dalam memperoleh informasi untuk menentukan keputusan strategis.

Aplikasi wizard merupakan tools yang khas atau unik digunakan dalam prosess pengembangan struktur yang baik, dengan menampilkan beberapa pertanyaan dan jawaban. Dan setiap langkah dalam wizard dimungkinkan dengan tampilan user interface yang baik (Burton, 2000 : p2), schingga mempermudah dalam pelaksanaan evaluasi software sistem informasi

\section{1,1 Identifikasi Masalah}

Berdasarkan kenyataan yang telah di sebutkan sebelumnya, maka identifikasi masalah dari penelitian ini dapat di rumuskan sebagai berikut:

a. Apa standard acuan yang diperlukan untuk evaluasi perangkat lunak?

b. Apakah Perangkat lunak yang digunakan sudah pernah dilakukan evaluasi dengan standard tertentu? 


\subsection{Ruang Lingkup Masalah}

Mengingat akan keterbatasan waktu, dan biaya maka ruang lingkup penelitian ini dibatasi pada Standard ISO 9126 merupakan acuan yang dapat digunakan untuk mengukur kualitas perangkat lunak di PT. SMI, khususnya untuk Program Penjualan.

\subsection{Perumusan Masalah}

Pcrumusan masalah ini adalah Bagaimana menyusun aplikasi untuk mengevaluasi perangkat lunak di PT. SMI dengan menggunakan Standard ISO 9126 ?

\subsection{Tujuan dan Manfaat Penelitian}

Tujuan Penelitian ini adalah:

a. Membangun aplikasi untuk evaluasi perangkat lunak dengan menggunakan Standard ISO 9126.

b. Mempermudah melakukan pengukuran terhadap kualitas perangkat lunak.

Sedangkan manfant dari penelitian ini dar beberapa segi yakni:

a. Memberikan manfaat praktis adalah hasil dari penilitian ini diharapkan bermanfaat bagi tim yang mempunyai tujuan untuk mengevaluasi software yang telah dimplementasikan di perusahaanya.

b. Memberikan manfaat tcoritis semoga dapat memberikan sumbangan bagi pengembangan teori pendidikan. Terutama dalam pengembangan quality assurance khususnya dibidang rekayasa perangkat lunak.

c. Diperolehnya informasi dengan evaluasi tinggi dengan kualitas perangkat lanak yang baik.

\section{LANDASAN TEORI}

\subsection{Jaminan Kualitas Perangkat Lunak}

Jaminan kualitas perangkat lunak menupakan suatu aktivitas perlindungan pada suatu proses secara keseluruahn dalam pengembangan perangkat lunak

\subsection{Kualitas Perangkat Lunak}

American Heritage Diennnary mendefinisikan kata kualitas sebagai "sebuah karakteristik atan atribut dari sesuatu." sebagai atribut, kualitas mengacu pada karakteristik yang dapat diukur, sesuatu yang dapat dibandingkan denan standar yang sudah diketahui.

\subsection{Pengukuran Produk Perangkat Lunak}

Pengukuran perangkat lurtak merupakan tema kajian yang turun temurun dalam sejarah rekayasa perangkat lunak (Sofrware Engineering). Kajian tersebut dapat diukur dari segi proses maupun produk.

\subsection{ISO 9126}

Salah satu standar kualitas untuk mengukur kualitas produk yang dihasilkan adalah 1SO 9126. standar ISO 9126 terbagi menjadi 4 (empat) bagian, yakni : model kualitas, intemal metric, external metric dan metric kualitas.

Enam karakteristik dari model kualitas sofiware adalah:

1. functionality yaitu kemampuan dari segi fungsi produk perangkat lunak yang menyediakan kepuasan kebutuhan user.

2. Reliability yaitu kemampuan perangkat lunak untuk perawatan dengan level performansi.

3. Usability yaitu atribut yang menunjukkan tingkat kemudahan pengoperasian perangkat lunak.

4. Efisiensi yaitu menyangkut waktu eksekusi dan kemampuan yang berhubungan dengan sumber daya fisik yang digunakan ketika perangkat lunak dijalankan.

5. Maintability yaitu tingkat kemudahan perangkat lunak tersebut dalam mengakomodasi perubahan-perubahan

6. Portability yaitu kemampuan yang berhubungan dengan kemampuan perangkat lunak yang dikirim ke lingkungan berbeda 


\subsection{Aplikasi Wizard}

Destgn wizard merupakan tool software yang menyatukan informasi yang berkaitan dengan reference architecture, implementasi dari komponennya dan interrelations. batasan-batasan yang dipergunakan dalam tool sesuai dengan komposisi yang sah. Design mempergunakan wizard merupakan generator tools dalam mengotomasi sebuah aplikasi yang berkaitan denan system families (Guillermo, 2000 ; $\mathrm{p}^{3}$ ).

\subsection{Kerangka Pemikiran}

Kerangka pemikiran model proses pengukuran perangkat lunak menurut standard ISO 9126 dapat diuraikan pada gambar di bawah ini:

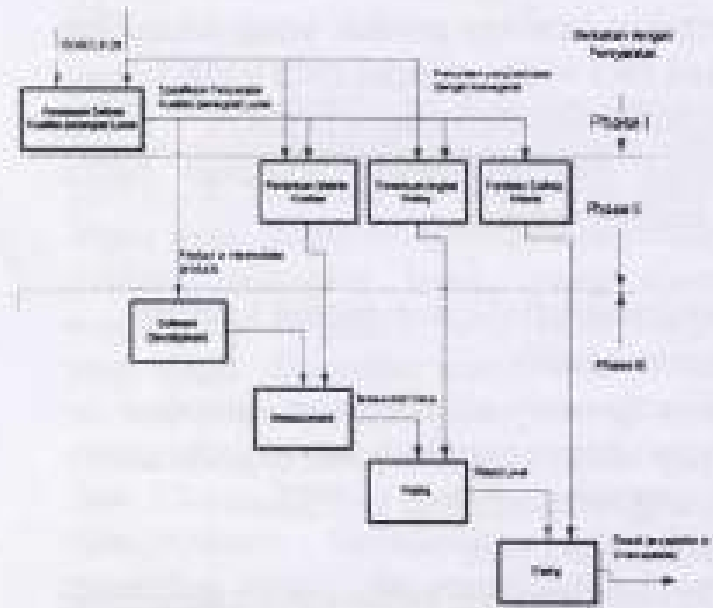

Gambar 1. Model Pengukaran Proses Pengukaran Perangkat Lanak

Gambar di atas menjelaskan mengenai langkah-langkah secara dalam pengukuran kualitas dari suatu perangkat lunak, yang terdiri dari 3 (phase) yaitu:

\section{a. Phase I}

Menentukan Kriteria/Karakteristik yang digunakan untuk mengukur kualitas perangkat lunak, dalam hal ini mengacu pada standard ISO 9126 dan persyaratan managerial yang telah ditetapkan pada dasar pembuatan software.

\section{b. Phase II}

Phase II yaitu menentukan bobot/Skala Metric dari masing-masing karakteristik maupun sub karakteristiknya Menentukan skala dari nilai kriteria sehingga diperoleh Rating Level dari hasil pengukuran. Menentukan Nilai dari tiaptiap kriteriz, dalam hal ini adalah Bunuk, Sedang, Bagus dan bagus sekali seperti gambar di bawah ini:

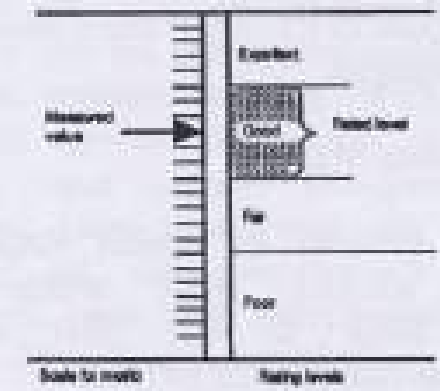

Gambar 2. Penentuan Bobor Penilaian

\section{c. Phase III}

Phase III melakukan pengukuran dan evaluasi dari tiap-tiap karakteristik yang telah ditentukan di Phase II. Sehingga dapat ditentukan hasil pengukuran dan evaluasinya.

Sedangkan kerangka pemikiran dalam proses kegiatan (framework) pengukuran kualitas perangkat lunak dapat dilihat gambar di bawah ini:

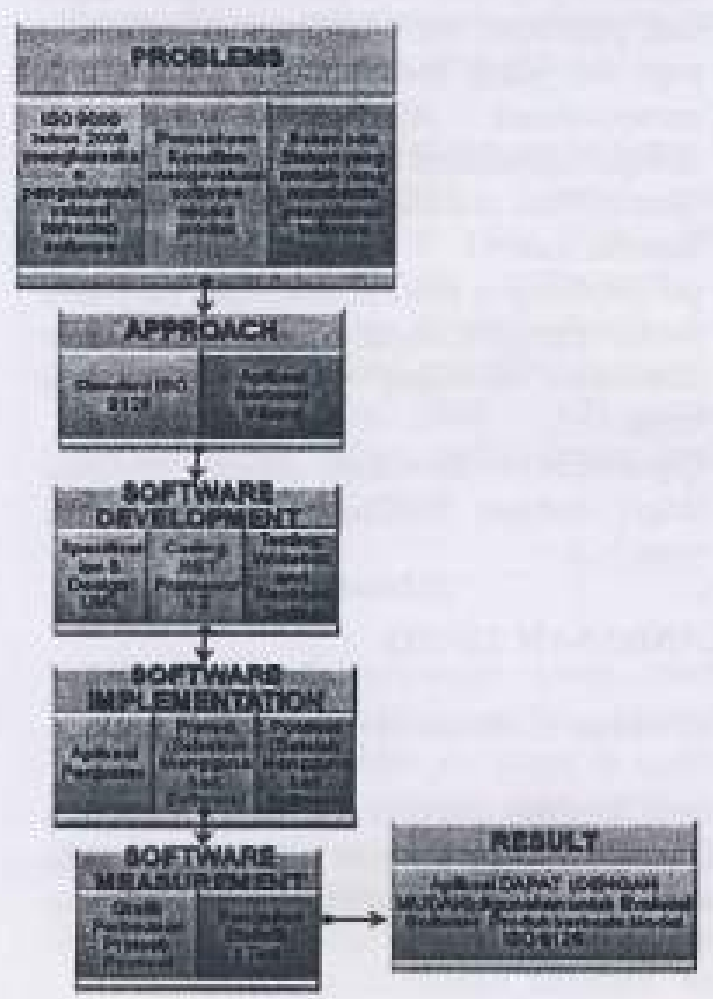

Gambar 3 Prases Kegiatan (Framework) Pengukaran Kualitas Peranghas Lumak

\section{METODE PENELITLAN}




\subsection{Permodelan menggunakan Use Case Diagram}

Permodelan menggunakan use case diagram akan menyajikan interaksi antara use case dan actor. Dimana actor dapat berupa user, peralatan, atau sistem liain yang berinteraksi dengan sistem yang sedang dibangun.

Use case diagram menggambarkan peryaratanpersyaratan yang harus dipenuhi sistem dalam hal ini pengembangan aplikasi wizard dari pandangan pemakai. Maka langkah-langkah yang dilakukan dalam mengembangkan aplikasi wizard sebagai berikut:

\subsection{Mengidentifikasi pelaku bisnis}

Pelaku dalam hal ini disebut sebagai Aktor yakni seseorang yang berhungan dengan aplikasi wizard. Aktor dalam pengguna aplikasi wizard harya scorang user saja. User dalam pengguna aplikasi wizard bisa seorang internal auditor IT, atau seorang yang ditugaskan dalam mengevaluasi sebuah aplikasi yang 5udah diimplementasikan. Seorang Internal Auditor mempunyai tugas untuk mengukur dan mengevaluasi aplikasi yang telah dikembangkan. Wewenang dari seorang internal auditor adalah menentukan dan memberikan nilai.

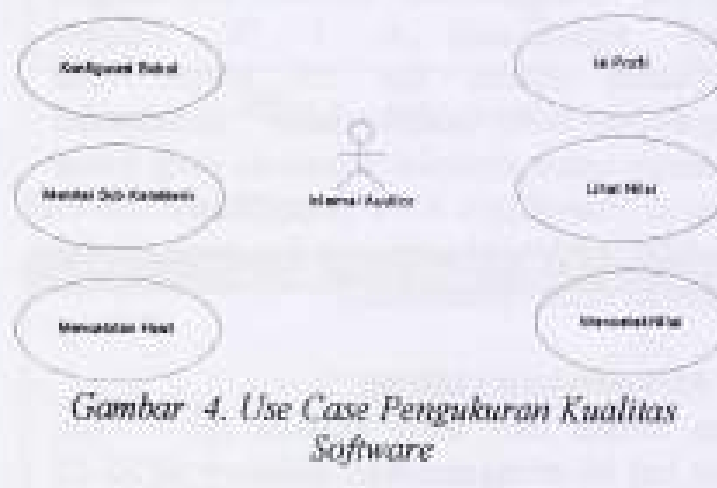

Gambar di atas menerangkan bahwa scorang user akan mengukur kualitas sebuah sofhware dari karakterisitik fungsi, reliabilitas, usabilitas, portabilias, maintaibilitas, efisiensi dan menganalisis hasil pengukuran evaluasi dari sebuah software, dalam bentuk aplikasi wizard Dari masing-masing karakteristik, kemudian dijelaskan ke dalam subkarakteristik pada use case diagram.
Langkah selanjutnya adalah Internal Auditor melakukan pengukuran sofherare dengan menentukan bobot/Skala Metric dari masingmasing karakteristik maupun sub karakteristiknya. Menentukan skala dari nilai kriteria sehingga diperoleh Rating Level dari hasil pengukuran. Use case tersebut menjelaskan pengukuran software dari segi fungsi sebuah software. Bagaimana fungsi sebuah software yang telah dibuat memberi kepuasan kepada penggunanya.

\subsection{Permodelan Menggunakan Class Diagram}

Setelah dibuat use case diagram, langkah selanjutnya adalah membuat Class Diagram berdasarkan use case diagram tersebut. Class diagram merupakan obyek-obyek yang terdapat dalam aplikasi wizard. Class diagram terdapat class konfigurasi bobot, profil,karakteristik dan taporan. Class diagram dari aplikasi yang dibuat digambarkan seperti di bawah in:

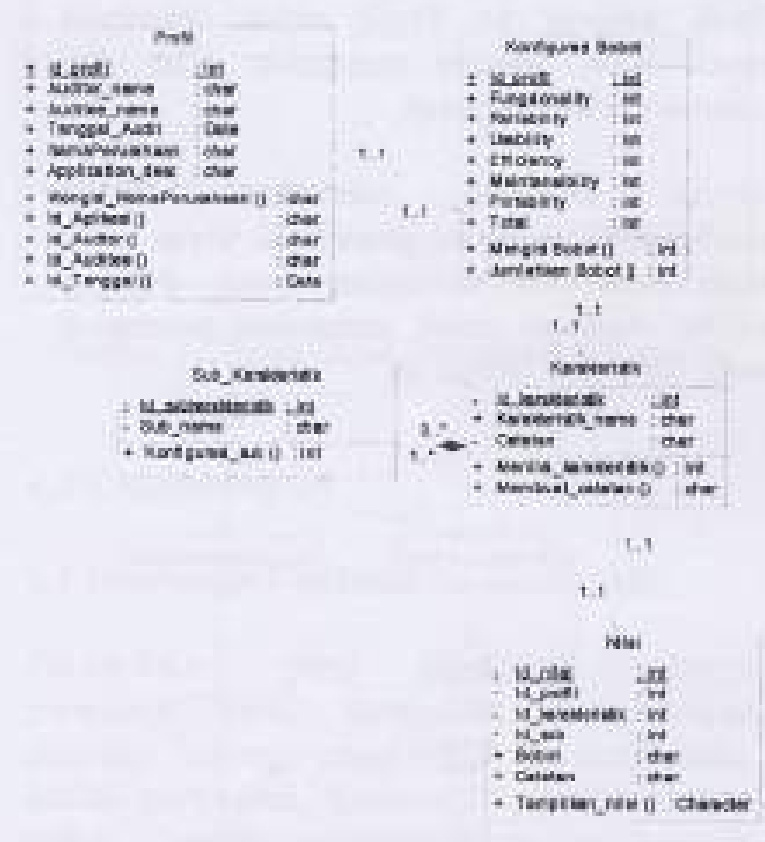

Gimbar 5. Claxs Diagnam

Sequence diagram untuk set modul kualitas perangkat lunak seperti pada gambar di bawah ini 


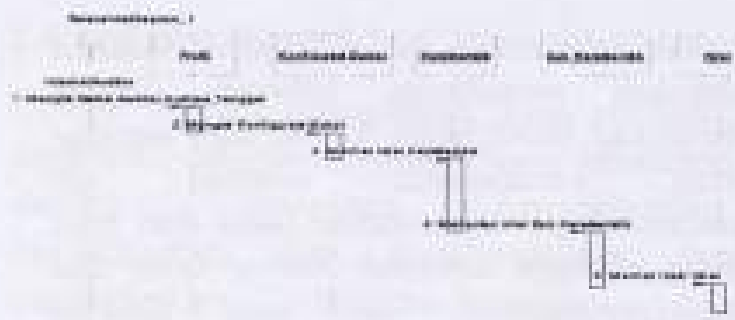

Gambar 6. Sequence Diagram untuk mengukur kualitas perangkat lamak

Diagram sekuensial yang menggambarkan obyck dengan interaksi obyek tersebut, dalam hal ini seorang user akan membuka wizard suitability yang berisi pertanyaan dan bobot nilai yang akan diberikan oleh user hasil dan mengisi sesuai dari hasil penilaian aplikasi yang diukur atau dievaluasi. Langkah awal adalah menuju ke Profil untuk membuat proyek baru, sampai mengukur nilai dan outputnya adalah laporan.

Activity diagram merupkan teknik mendiskripsikan logika prosedural, aliran kerja dalam mengukur perangkat lunak. Berikut activity diagram untuk mengukur perangkat lunak, seperti di bawah ini :

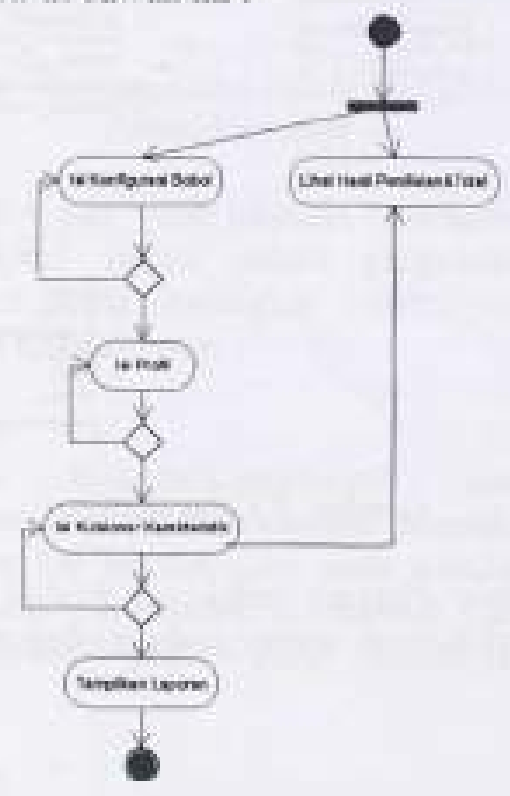

Gombar 7. Acriwity Diagnam Mengevaluasi Perangkat Lunak

\subsection{Teknik Analisis}

\section{Proses Pembandingan Hasil Pre-Test dan Post-Test}

Pada bagian ini akan dilakukan proses pembandingan hasil pengukuran penelitian yang telah didapatkan sebehumnya. Adapun metode pembandingan ini adalah dengan $\mathrm{Uji}_{\mathrm{ji}}$ T-Test (Paired Sample T Test). Metode ini digunakan karena $t$-test dapat digunakan untuk menguji kecocokan atas perbedaan pada suatu eksperimen yang menggunakan satu kelompok sampel. Apabila sebelum melakukan eksperimen, peneliti melakukan pengukuran awal (pre tesi), maka peneliti akan mempunyai dua kelompok nilai yang berasal dari satu kelompok sampel. Apabila eksperimen itu mempunyai dampak terhadap hasil (tujuan eksperimen), maka kedua kelompok skor tersebut akan menunjukkan perbedaan yang signifikan. Apabila hasil perhitungan tersebut berbeda secara signifikan. maka hipotesa diterima. Langkah-langkah pengujian sebagai berikut :

\section{a. Menentukan Hipotesis}

Ho : Tidak ada perbedaan antara pre-test (sebelum menggunakan aplikasi) dengan Post-Test (setelah penggunaan aplikasi).

\section{b. Menentukan tingkat signifikansi}

Pengujian menggunakan uji dua sisi dengan tinggal signifikansi a: $5 \%$. Tingkat signifikansi dalam hal ini berarti kita mengambil risiko salah dalam mengambil keputusan untuk menolak hipotesis yang benar sebanyak-banyaknya $5 \%$ (signifikansi $5 \%$ atau 0,05 adalah ukuran standar yang sering digunakan dalam penelitian).

\section{c. Menentukan t hitung}

Dapat dilihat dari hasil analisis uji $T$ Test, dalam hal ini menggunakan software SPSS 15 untuk mengnalisis $\mathrm{Uji}_{\mathrm{ji}} T$ Test tersebut.

\section{d. Menentukan I Tabel}

Tabel distribusi $t$ dicari pada $a=5 \%: 2=2,5 \%$ (uji 2 sisi) dengan derajat kebebasan (df) $n-1$.

\section{e. Kriteria Pengujian}

Ho diterima jika $-t$ tabel $\leq t$ hitung $\leq t$ tabel

Ho ditolak jika $-t$ hitung $<-t$ tabel atau $t$ hitung $>$ t tabel 
Berdasar probabilitas :

Ho diterima jika $P$ value $>0.05$

Ho ditolak jika $\mathrm{P}$ volue $<0,05$

\section{f. Membandingkan thitung dengan t tabel dan probabilitas}

Dari hasil perhitungan tersebut, maka $t$ hitung akan dibandingkan dengan $t$ tabel. Jika perbedaannya sugnifikan, maka disimpulkan bahwa hipotesa diterima. perhitungan t-test dengan lebih mudah dan cepat tanpa perlu melakukan perhitungar.

\subsection{Antar Muka Pengguna}

Graphical User Interface (GUI) merupakan antar muks pengguna suatu program berbasis grafis, yakni perintah-perintah tidak diketik melalui key board, berikut adalah beberapa tampilan antar pengguna untuk berinteraksi dengan sistem

\section{a. Form Awal}

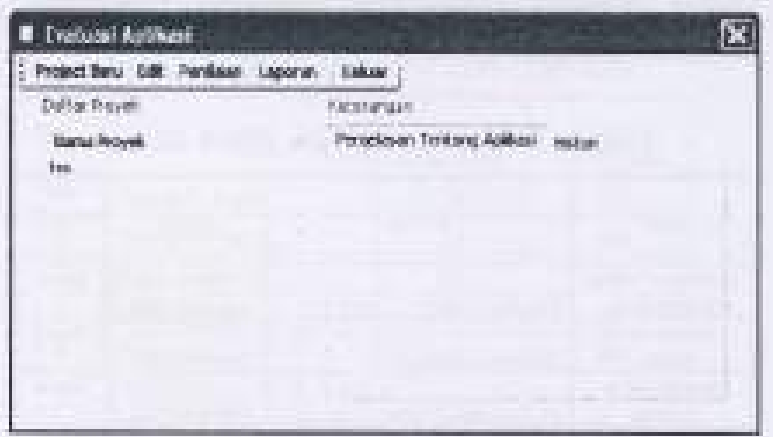

Gambar 8. Form Awal Penguikuran knalitas

\section{b. Form Profil}

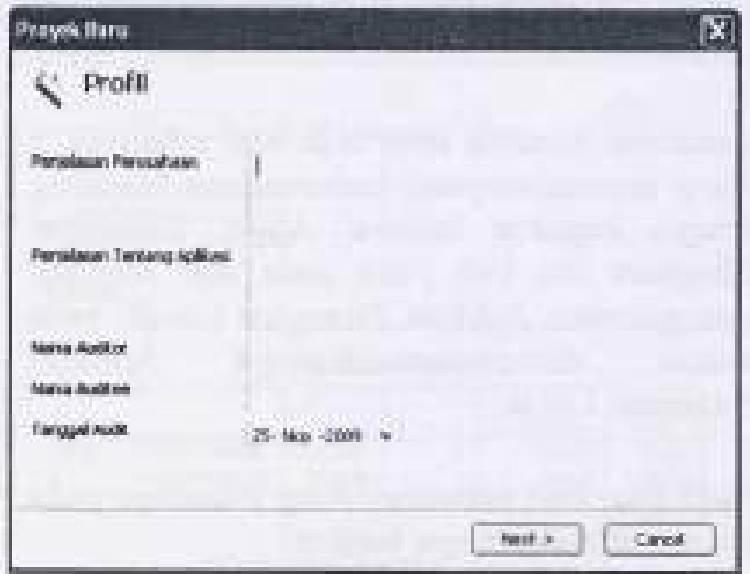

Gambar 9. Farm Profil Proyek Baru

\section{c. Form Konfigurasi Bobot}

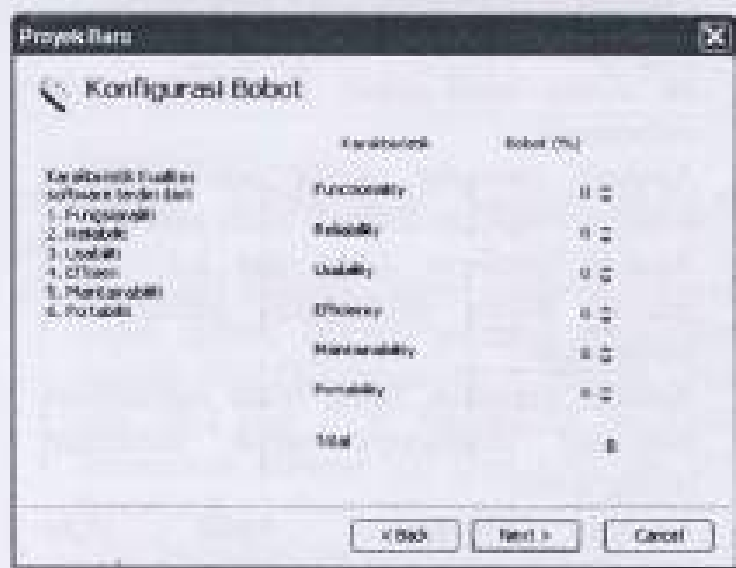

Gambar 10. Form Konffgurasi Bobot

\section{d. Form Laporan}

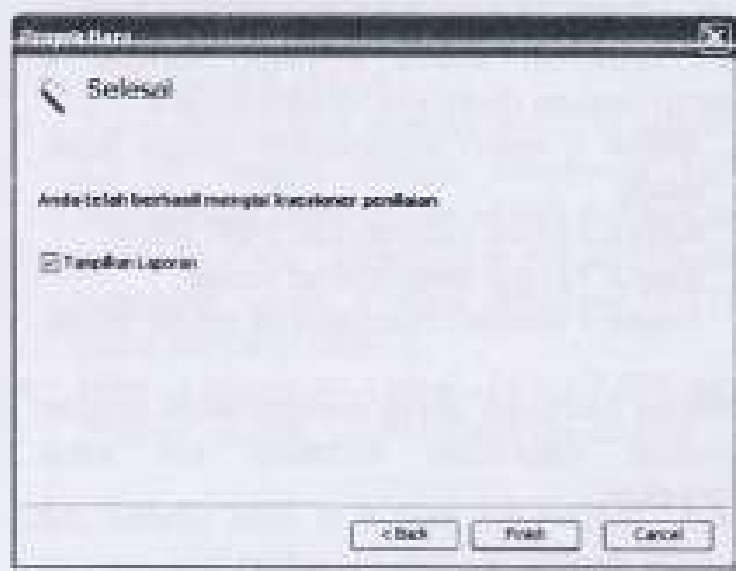

Gambar II. Form Untuk Menampilkan Laparan

\section{PEMBAHASAN}

\subsection{Instrumen Penilaian Implementasi}

Faktor-faktor yang digunakan sebagai parameter untuk mengukur mempercepat aktivitas berbagi pengtahuan di perusuhaan adalah partisipasi, motivasi, kemudahan, dan waktu. Dengan memperhatikan aspek-aspek tersebut, maka disusunlah item kuesioner sebagai berikut

a. Apakah menurut Anda saat ini, mengevaluasi perangkat lunak secara berkala mudah ditelusuri ?

b. Apakah meunut Anda intemal andit untuk mengevaluasi perangkat lunak saat ini lcbih akurat ? 
c. Apakah menurut Anda melakukan evaluasi atau internal audit lebih mudah?

d. Apakah menurut Anda, internal audit saat ini Anda lebih cepat dalam penyajian informasi?

c. Apakah menurut Anda lebih mudah membuat laporan internal audit saat ini?

f. Apakah menurut Anda saat ini lebih mudah dalam melakukan pertanyaanpertanyaan ?

g. Apakah menurut Anda lebih melakukan penilaian khususnya untuk membuat nating level?

h. Apakah menurut Anda akan mempergunakan lagi Aplikasi untuk melakukan evaluasi?

Pertanyaan-pertanyaan tersebut diukur dengan skala Likert. Skala Likert merupakan bentuk skala penilaian antara 1 (satu) sampai 4 (empat) dengan deskripsi sebugai berikut:

a. Angka 1 (satu) menyatakan sangat tidak setuju

b. Angka 2 (dua) menyatakan tidak setuju

c. Angka 3 (tiga) menyatakan setuju

d. Angka 4 (empat) menyatakan sangat setuju

Skala ini berfungsi untuk menunjukkan tingkat kepuasan responden terhadap hal yang ditanyakan.

\subsection{Pengujian Aplikasi}

Aplikasi wizard yang telah dibuat, selanjutnya diuji melalui teknik pengujian perangkat lunak yang melipati pengujian white box.

\section{a. Pengujian Aplikasi Pengujian White Box}

Metode white box ini adalah suatu metode desain test case yang menggunakan struktur kontrol desain prosedural untuk memperoleh test case, Dengan menggunakan metode pengujian white box, perekayasaan sistem dapat melakukan test case yang dapat:

1. Memberikan jaminan bahwa semua jalur independen pada suatu modul telah digunakan paling tidak satu kali.

2. Menggunakan semua keputusan logis pada sisi true dan false.

3. Mengeksekusi semua loop (perulangan) pada batasan mereka dan pada batas operasional mereka
Dalam hal ini, pengujian tidak dilakukan terhadap keseluruhn program secara utuh, namun dilakukan sampel pengujian terhadap proses tertentu.

Pengujian white Box terhadap proses konfigrasui bobot, secara garis besar, algcritma dari proses login adalah sebagai berikut.

1. masukan nilai karakteristik

2. jika jumlah mencapai $100 \%$

3. bila terjadi kurang atau lebih dari 100 persen dari total tampilkan pesan kesalahan

4. lakukan pengisian data baru seperti langkah (a)

5. bila telah mencapai total $100 \%$, maka user dapat mengakses sistem.

\section{b. Pengujian Aplikasi Pengujian Blcak Box}

Pengujian selanjutnya dilakukan untuk memastikan bahwa suatu event atau masukan akan menjalankan proses yang tepat dan menghasilkan output sesuai dengan rarcangan. Untuk contoh pengujian terhadap beberapa perintah sebagai berikut :

Tabel 3. Hasil penguijian Black Bax

\begin{tabular}{|c|c|c|c|}
\hline ent & Awitit & atout & $\begin{array}{c}\text { ians } \\
\text { mingun } \\
\text { r }\end{array}$ \\
\hline 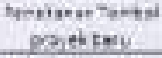 & 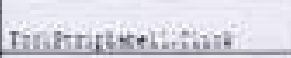 & $\begin{array}{l}\text { Uetwit } \\
\text { insethistit }\end{array}$ & Selse \\
\hline 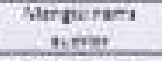 & 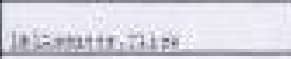 & $\tan 4=20$ & than \\
\hline $\begin{array}{c}\text { Merguirary } \\
\text { sseet }\end{array}$ & 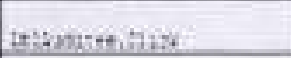 & Anerviluter & yess \\
\hline $\begin{array}{c}\text { Mrepinsoes } \\
\text { pipt }\end{array}$ & 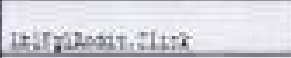 & Therevise & SKS-k \\
\hline 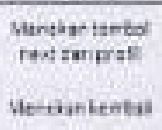 & 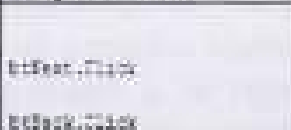 & 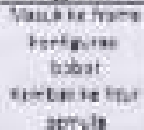 & sticy \\
\hline $\begin{array}{l}\text { Merelar fanted } \\
\text { therionilogoar }\end{array}$ & 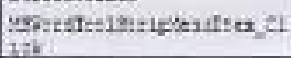 & $\begin{array}{l}\text { Neritphin: } \\
\text { jeown }\end{array}$ & $\operatorname{ses} x$ \\
\hline
\end{tabular}

Kuesioner tersebut diisi oleh staf sebanyak 5 orang responden yang berhubungan langsung dengan kegiatan Intemal Audit. Kuesioner dibagikan dua kali yaitu pada saat sebelum menggunakan Aplikasi Perangkat Lunak, serta setelah diimplementasikannya Aplikasi Perangkat Lunak.

Hasil nilai dari kuesioner yang diberikan pada pre-test adalah sebagai berikut: 
Tabel f. Hasil Pre-Test

\begin{tabular}{|c|c|c|c|c|c|c|c|c|c|c|}
\hline \multirow{2}{*}{ No. } & \multirow{2}{*}{ Nama } & \multicolumn{8}{|c|}{ Dertanyean } & \multirow{2}{*}{ Tetal } \\
\hline & & 1 & 2 & 3 & A & 5 & 6 & 9 & E & \\
\hline 1 & Poseph anto & 2 & 2 & 2 & 1 & 1 & 2 & 1. & 1 & 12 \\
\hline 2 & Mini Mavini & 1 & 2 & 1 & 2 & 1 & 2 & 1 & 2 & 11 \\
\hline 3 & Agunsukece & 1 & 1 & 2 & 2. & 2. & 2 & 1 & 2 & 12 \\
\hline 4 & Tts. Ange & 1 & 1 & 1 & 1 & 1 & 3 & 1 & 1 & 8 \\
\hline 3 & Tas: & 2 & $t$ & 1 & 3 & 1 & 2 & 1 & 2 & 8 \\
\hline
\end{tabular}

Setelsh diimplementasikan sistem selanjutnya disebar kuisioner tahap kecua untuk mengukur dampak implementasi sistem, hasil nilai dari kuesioner yang diberikan adalah sebagai berikut:

Tabel 5. Hasil Pass-Test

\begin{tabular}{|c|c|c|c|c|c|c|c|c|c|c|}
\hline \multirow{2}{*}{ vo. } & \multirow{2}{*}{$\operatorname{tana}$} & \multicolumn{8}{|c|}{ Petricast } & \multirow{2}{*}{ Total } \\
\hline & & 1 & 2 & 3 & 4 & 5 & 6 & 7 & 5 & \\
\hline 1 & Bangh dain & 3 & 2 & 3 & 2 & 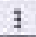 & 3 & 3 & 3 & 12 \\
\hline 1 & FiniMarni & 4 & 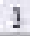 & 1 & 1 & 1 & 2 & I & 3 & is \\
\hline 1 & Measyose & 3 & 1 & 1 & 2 & 1 & 2 & 4 & 1 & 12 \\
\hline 4 & Hakga & 3 & 4 & \pm & 2 & 2 & 3 & 2 & $i$ & i \\
\hline 1 & Ins & 3 & 4 & 1 & 3 & 2 & 3 & 3 & 1 & 3 \\
\hline
\end{tabular}

Dari data hasil pre test dan post test yang telah dilakukan sebelumnya, dapat diringkas menjadi tabel berikut ini:

Tabel 6. Hasil Pre-Test dan Post-Test

\begin{tabular}{|c|l|c|c|}
\hline No. & \multicolumn{1}{|c|}{ Nama } & Pra-Test & Poit-Tast \\
\hline 1 & Yosephanto & 12 & 22 \\
\hline 2 & Rini Marini & 11 & 23 \\
\hline 3 & Agus Suhoto & 12 & 23 \\
\hline 4 & Yts. Angga & 8 & 21 \\
\hline 5 & Tat & 8 & 23 \\
\hline
\end{tabular}

Data tersebut adalah hasil rangkuman dari hasil kuesioner yang sudah dijelaskan pada bab sebelumnya. Dari data tersebut, lalu data digenerate menggunakan fungsi data anohysis dari spss 15 dan akan menghasilkan tabel berikut:

\section{Takel 7. Hasd T-Test}

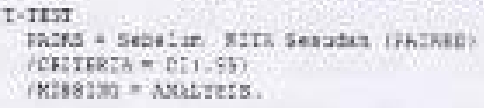

T-Test

\begin{tabular}{|c|c|c|c|c|c|}
\hline \multicolumn{6}{|c|}{ Futne donplen shastos } \\
\hline & & vem & 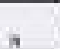 & Pt Demen: & gr Enir \\
\hline pro & 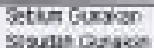 & $\begin{array}{l}10,2000 \\
20400\end{array}$ & 8 & 200433 & 9162 \\
\hline
\end{tabular}

\begin{tabular}{|c|c|c|c|c|}
\hline \multicolumn{5}{|c|}{ Peod Ianfles Camelatus } \\
\hline & & w & लism & $x$ \\
\hline in & Sesumen Quesest & 4 & $z$ & 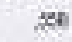 \\
\hline
\end{tabular}

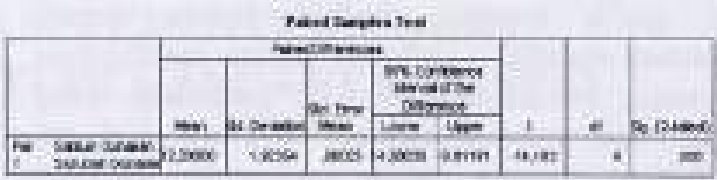

Dan tabel T-Test dapat dianalisis sebagai beirkut

a. Dari hasil analisis Paired samples slatitics dapat dilihat bahwa variabel responden jumlah data $(\mathrm{N})$ sebanyak 5 dengan ratarata 10,2 dan 22,4 . Sedangkan standard deviasinya sebesar 2,0 (pre test) dan 0,8 (post test).

b. Dari hasil analisis korelasi yang digunakan untuk mengetahui hubungan antara dua variabel dan untuk mengetahui arah hubungan yang terjadi. Maka korelasi yang terjadi adalah 0,355 .

c. T hitung dari tabel di atas didapat nilai t hitung adalah $-14,182$

d. Tabel distribusi $t$ dengan $a=5 \%$ adalah $2,5 \%$ dengan derajat kebebasan (df) berdasarkan tabel di atas adalah 4 . Dengan penujian 2 sisi (signifikansi $=0,025$ ) hasil diperoleh untuk $t$ tabel sebebsar 2,776 (lihat lampiran tabel $\mathrm{t}$ ).

e. Nilai $-t$ hitung $<-t$ tabel $-14<-2,776$ dan $P$ value $(0,000<0,05)$ maka Ho ditolak.

Oleh karena nilai $-t$ hitung $<-t$ tabel dan Pvalue < ), 05 maka Ho ditolak, artinya bahwa ada perbedsan yang signikan antara sebelum dan setelah penerapan aplikasi wizard efektif.

Apabila tabel hasil pre test dan post test digambarkan menjadi grafik, maka akan tampak perbedaan hasil dari sebelum dan sesudah penerapan aplikasi wizard utnuk mengevaluasi penangkat hunak.

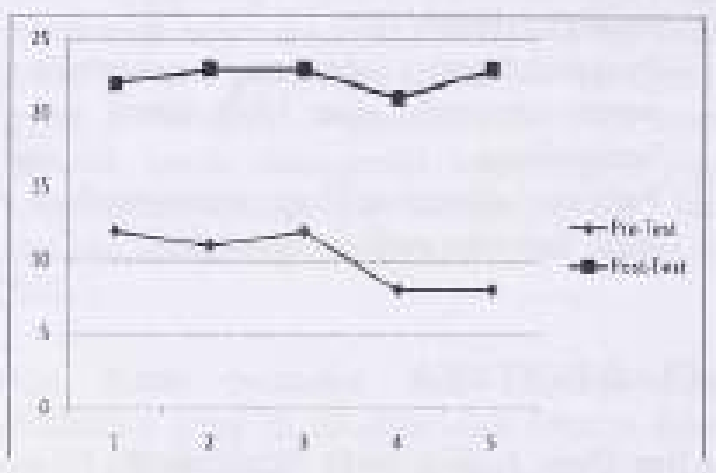

Gimbar 8 . Pre-Test daut Post-Text 
Dari grafik tersebut, terlihat bahwa terjadi perbedaan signifikan terhadap hampir keseluruhan karyawan. Namun terlihat juga perbedaan yane sangat tipis pada beberapa karyawan. $\mathrm{Hal}$ in disebabkan karena pada karayawan tersebut sebelumaya telah terbiasa mengaplikasikan mind map dan berbagi pengetahuan dengar menggunakan alat bantu.

\section{SIMPULAN DAN SARAN}

\subsection{Simpulan}

Dari hasil penelitian yang dilakukan mulai dar tahap awal hingga proses pengujian, dapat disimpulkan bahwa dengan dimplementasikannya aplikasi wizard untuk pengukuran perangkat lunak di perusahaan yang menjadi objek penelitian maka dapatd disimpulkan sebagai berilkut:

a. Standard acuan yang digunakan untuk cvaluasi perangkat dalam hal ini adalah standard ISO 9126 dapat digunakan untuk mengevalunsi perangkat lunak di PT. SMI

b. Aplikasi wizard untuk mengukur evaluasi perangkat lunak dapat dipergunakan Iebih efektif dan mempermudah pekerjaan terutama untuk mengevaluasi aplikasi penjualan di PT. SMI

\subsection{Saran}

Adapun saran-saran yang dapat penulis berikan adalah sebagai berikut.
a. Perlu dikembangkan dengan versi berikutnya
b. Pengembangan intergrasi dengan audit internal
c. Pengembangan standard untuk bobot perangkat lunak
d. Pengembangan dengan cussomize pertanyaan audit agar lebih detail dan berkembang.
e. Perlunya dibuat aplikasi menggunakan
lebih dari satu auditor dan auditee.

\section{DAFTAR PUSTAKA}

Bee Bee Chua, L. E (2004). Applying the ISO 9126 model to the evaluation of an elearning ASCILITE, 184-190.
ISO. (2008). Standard ISO 9001:2008. Genewa: ISO Standard

ISO/IEC. (9001), ISOIEC 9126 - Sofhuare Product Evaluation-Quality Characieristics and Gudelines for their Use. Genewa: ISO Standard.

Jiménez-Pérez, G. (n.d). Design Wizards for Software Product Lines. Centro de Investigación en Informática

Munawar. (2005). Permodelan Visual dengan UML. Yogyakarta: Graha Ilmu.

Myatt, A. (2008). Pro NetBeans IDE 6. New York: Apress.

Nugroho, A. (2005). Rationale Rose untuk Permodelan Berorientasi Objek

Bandung: Penerbit Informatika.

Penyusun, T, (2009). Buku Pedoman Penulisan Proposal dan Tesis. Jakarta: Eresha Eduacation Indonesia.

Pressman, R. S. (2003). Rekayasa Peranghat Lunak Yogyakarta: Penerbit ANDI.

Sutarto, R. H. (2009). Konsep pemrograman IAVA dan Penerapannja untuk membiat software aplikasi. Jakarta: Gramedia.

Wahono, R. S. (2006), Pengukuran Kualitas Perangkat Lunak. Majalah SDA .

Priyatno, D. (2009). Mandiri Belajar SPSS untuk Analisis Data dan Uji Statistik. 